\title{
Inter-regional Mobility of Entrepreneurial SMEs
}

\begin{abstract}
Expanding, entrepreneurial, enterprises move from high cost (congestion, wages and rent) locations where they innovated to low cost (smaller, less agglomerated) places suitable for standardised production. Net inter-regional relocations of British SMEs are predicted in part by this development pattern. SMEs that relocate are more productive, relatively larger and younger, as well as more probably initially located in London and the South East (core locations). These fast growing businesses become even more productive and employ even more workers after moving than regionally immobile SMEs. In this respect the UK regional core supports the periphery through a market process. Relocation is also a strategy for contracting enterprises, but not necessarily a helpful for smaller companies.
\end{abstract}

Word count: excl. references, abstract and tables

Key words: Spatial mobility - SMEs - firm strategy and growth- regional convergence- entrepreneurship JEL: R11 R12 L21 L25 


\section{Inter-regional mobility of entrepreneurial SMEs}

\section{Introduction}

Fast growing entrepreneurial firms, or 'gazelles', are rare (OECD 2013). Yet, based on successful innovation, they are an important source of indigenous productivity and employment if they stay put. As they expand local conditions, initially favourable to their formation, often are no longer optimal for their current production and marketing requirements (van Dijk and Pellenbarg 2000; Brouwer et al 2004; Hu et al 2008). They may therefore relocate between regions, transferring skills and jobs. Such mobility can occur because innovation takes place in an agglomerated centre where information and diverse resources are abundant but factor costs are high. Once the product or process is standardised, the innovating firm has an incentive to move to lower cost locations and export from there (Vernon 1966; Duranton and Puga 2001). Impacts of spatial mobility on the enterprise itself may be intended or unintended. In addition to different factor scarcities, many firms that relocate experience substantial benefits or challenges to efficiency because of the adjustments they are required or enabled to make at their new sites - and perhaps because of the way they frame the management problem (Loasby 1988, 2000).

A vital policy concern is that relocations may be a positive feedback of market processes, exacerbating regional disparities in economic activity; entrepreneurial firms remove their dynamism to areas that are already dynamic. This type of behaviour, aggravating regional differences, is a common prediction of New Economic Geography (NEG) models (Krugman 1991: Venables 2006). On the other hand, classical and neoclassical trade and growth theories predict that markets encourage spatial convergence (e.g. Barro and Sala-i-Martin 2004 ch13).

In both approaches, spatial economic patterns are changed by the movement of goods, of factors of production and of firms. Understanding the working and magnitude of each process is essential to appreciate the overall influence of the various forces. In practice the impact of each movement may differ, in which case their net effect on geographical activity must be uncertain without investigating all of them. The present research is concerned only with a subset of one of these processes; the inter-regional mobility of SMEs. A motivation is that UK policy makers identified firm immobility as a potential barrier to the convergence of regional growth and productivity (HM Treasury 2001 34-37).

Taylor and Wren (1997) concluded that UK regional policy had been too inadequately funded to be effective. Since this assessment, funding has not become more generous and EU structural funds apparently have not yielded high returns (Rodriguez-Pose and Fratesi 2004). A reasonable conclusion is that the 
number of firms moving between regions recently is unlikely to have been substantially influenced by national policy; mobility must have been driven primarily by market forces.

In the present paper we examine the relocation of SMEs using a very large UK data set with comprehensive coverage to assess whether the process reinforces core-periphery disparities, as in many NEG models, or ameliorates them in neoclassical style. Section 2 is a brief literature review of firm relocations from which is derived hypotheses about the mobility of entrepreneurial SMEs. Next (section 3), the data set that allows tests of these hypothesis is described. Preliminary evidence is presented both that spatially mobile firms are more dynamic than the average of their originating region and that the dominant tendency is for such enterprises to move from the geographical core to the periphery. In section 4 multivariate analysis shows the characteristics of, and explanations, for the probability of the individual SME's relocation. Spatially mobile SMEs are more productive, usually larger and younger. They are more likely to be registered as companies, taken-over and originally based in London and the South East (core locations). Consistent with successful entrepreneurship, expanding mobile enterprises are shown to increase productivity and employment strongly as a result of their move. In combination these effects suggest a neoclassical convergence process is a better description of inter-regional SME relocations than the increasing regional disparities predicted by NEG.

\section{Spatial Economic Patterns and SME Relocation}

Two major theories, neoclassical trade and growth, predict spatial economic convergence, but when their assumptions about knowledge, technology and innovation are altered, the modified or new theories can predict divergence and spatial concentration of economic activity. We outline these models and derive testable hypotheses about the mobility of entrepreneurial SMEs.

According to classical trade theory immobile regional resources, whether human or natural, ensure that regional production will become specialised to export goods and services in which the location has a comparative advantage ${ }^{1}$. Regions will be mutually supportive, exhibiting a division of labour by their differences in industrial structure. Trade flows in the (Hecksher-Ohlin) theory ensure that regional product prices tend to equalise and therefore so do factor prices; regional wages will converge (Samuelson 1948). The sources of regional specialisation probably include region- or firm-specific tacit knowledge. Unlike codified knowledge, tacit knowledge, along with the labour that bears the knowledge, is likely to be immobile (Asheim and Gertler, 2005). This will mean that regional technologies may differ and therefore so will regional wages. On the other hand, to the extent that firms move between regions they will bring their tacit knowledge with them.

\footnotetext{
${ }^{1}$ Although all regions will have similar industries that supply products not traded between regions.
} 
The conditional regional convergence predicted by neoclassical growth theory (albeit empirical estimates suggest at a slow rate) does not necessarily imply actual convergence (Barro and Sala -i-Martin 2004 ch13). First, region-specific shocks may dominate, increasing dispersion. Second, the condition of similar region steady states, determined in this context primarily by 'technology', may not be satisfied as already discussed. The convergence prediction derives from diminishing returns to individual factors in an aggregate production function; regionally these are registered by the level of congestion and rents, as manifestations of the scarcity of space, and may be drivers of business relocation. A third reason for an absence of actual convergence is that the prediction depends upon constant returns to scale in the production function. When returns to scale increase, the convergence prediction is replaced by divergence; regions that get ahead, stay ahead.

Why should returns to scale increase? One reason may be because technical progress is institutionalised and offsets diminishing returns to individual factors. Agglomeration economies are another source of increasing returns. Agglomeration economies can be static, reflecting external economies. Or in dynamic form, by the encouragement of innovation and entrepreneurship, diversity may be one channel through which agglomeration creates a continuing regional advantage (Lee, Florida and Acs 2004). Other things being equal, greater variety will be found in larger concentrations of people. In the same direction an analogy to Ronald Fisher's (1930) 'theorem' of natural selection, indicates that competition in a location is more intense when there is greater variety of competitors and complementary support, and this makes for higher productivity growth ${ }^{2}$.

Tacit knowledge is a vital source of the geography of innovation and therefore of entrepreneurship and economic dynamism (Asheim and Gertler, 2005). Appropriating the returns from this knowledge generated by an existing business can encourage the latent entrepreneur to cease employment and establish a new firm (Audretsch 1995, 179-80; Audretsch and Lehman 2005). Yet, chance and lock-in may dissipate the effect for some regions. Existing industries provide the knowledge base for would-be local entrepreneurs, and some sectors have greater development potential than others. With the 'wrong' industrial base, innovation and entrepreneurship will be muted, and innovation determines the dynamic consequences of a given spatial structure (cf. Checkland 1976).

Regional innovation potentials may differ because of their innovation systems, as well. An innovation system is the interactions between firms, infrastructure, institutions and systems of finance, governance and education that combine to promote innovation, especially for clusters of knowledge-based industries, and for knowledge spillovers (Asheim and Coenen 2005; Cooke 2002; Fagerberg 2005). Innovation performance is

\footnotetext{
${ }^{2}$ The theorem is that the rate of increase in fitness of any organism at any time is equal to its genetic variance in fitness at that time. The analogy requires replacing 'genetic variance' by variety of innovatory strategies, resources and ideas, 'organism' by a city or region, 'fitness' by economic dynamism and 'natural selection' by 'competition'.
} 
thus linked to various patterns of cooperation, to policy and to learning (Lundvall 1999). SMEs, embedded in industrial districts, in clusters and in learning regions, where networks, external economies, culture and institutions favour productive and innovative working, may be particularly likely to become 'gazelles'.

New Economic Geography (NEG) models especially utilise increasing returns or agglomeration economies (Baldwin and Forslid 2000: Baldwin and Okubo 2006). They commonly derive predictions in spatial form comparable to those of endogenous growth models, namely that development is centripetal; smaller, peripheral regions lag increasing behind larger, central places. In these models small initial changes may have large long term effects (e.g. Krugman 1991: Venables 2006).

Processes reinforcing centralisation include capital movements between regions in a national economy that will be governed by perceived opportunity. Perceptions are likely to be shaped by location; information will probably attenuate with distance from the financial centre, and information may be one source of agglomeration economies. Even SMEs, as high risk businesses depending primarily on owner's equity and ploughed back profits, can be affected by the consequent financial scarcity in the periphery. Similarly Ravenstein's (1885) laws of migration for people, which first hinted at a gravity model, show populous area attract more migrants, and another process by which spatial activity is concentrated.

On the other hand, models of innovative activity that are based exclusively on firm-level, rather than regionspecific, determinants are able to produce extremely good predictions (Copus et al 2008; Sternberg and Arndt (2001), Bok and van Ort (2011) find that firm relocation behaviour is affected much more by firmlevel attributes (size, age, and growth rate) than by agglomeration and accessibility attributes. A link between firm- and region-level relocations of innovatory firms may be found when innovation takes place in an agglomerated centre where information and diverse resources are abundant. But once the product or process is standardised, the innovating firm has an incentive to move to lower cost locations and export from there (Duranton and Puga 2001). In this way an SME mobility convergence mechanism kicks in.

In other words, some firms will relocate because of the stage in the establishment's life cycle or strategy (van Dijk and Pellenbarg 2000), for a firm's requirements and preferences for locations will change as it expands (Holl 2004). The initial site of a start-up firm is likely to depend on the entrepreneur's prior location. Firms in residential areas are likely to be start-ups with a high propensity to move to a more suitable location as they grow (Knoben and Oerlemans 2008). Gudgin (1978 p. 129) found that entrepreneurs established firms close to their former place of employment and in the same trade. Sometimes they were locally born and bred. Lack of capital, local knowledge of market opportunities, reliable workers and premises and the need to begin on a part time basis, all tied production to the home area. By contrast the SME's relocation decision is likely to be less constrained (Manjon-Antolin and Arauzo-Carod 2011). Limited access to financial resources might ensure the entrepreneur's home is the only feasible initial 
business premise. To these factors, Stam (2007) added personal contacts and networks only available in the 'home' region. Most entrepreneurs who consider moving away from their home region do not do so because of highly valued personal relationships (Figueiredo et al 2002).

The product and investment life cycle (Vernon 1966) suggests that in the first innovative stage, the firm needs to be close to centres where ideas and opportunities are generated, despite the high costs of location, in order to modify the infant product or process appropriately (Audretsch and Feldman 1996). Dynamic firms' strategies will include their location policies (Galbraith et al 2008; Stam 2007). In the later phase of expansion to the standardised product and large scale production, firms might move to areas that offer lower costs and more services, as well as space that allows expansion. Fothergill and Gudgin (1982 ch.5) found that space constraints for growth was the dominating feature of the UK manufacturing employment shift from city to countryside and small towns in 1980s.

In such a conception of the innovative firm, origin and destination locations might complement each other; the assets of the origin region are better suited to innovation and those of the destination region are more appropriate for standardised production. The prosperities of the two areas are interdependent. We derive from this life cycle model of relocation of the entrepreneurial firm hypotheses about age of the firm, productivity, employment or size, legal form, takeovers and spatial pattern of movement.

Younger units are more likely in the early phase of the cycle, probably more dynamic and perhaps expected expansion encourages them to relocate to more spacious premises. They are more probably ready to make the transition from the innovative to the standardised stage. Age may additionally reflect how embedded a given unit is in the locality, also affecting the chances of relocation. In this case;

\section{H1 Corporate age will predict the chances of a firm relocating.}

An entrepreneurial firm is more likely to consider restructuring and to relocate for this reason (Coucke et al. 2007). As the preceding discussion indicates, firms may move to expand their labour force, to reduce their unit labour costs or to alter their capital-labour ratio (Nakosteen and Zimmer 1987). Enterprises that are willing to consider improving their position by moving are likely to be controlled by energetic management who have already fully exploited what can be achieved in their present location. For these reasons and those underlying $\mathrm{H} 1$;

H2a More productive SMEs are more likely to relocate.

And

$H 2 b$ Expanding SMEs that relocate are likely to become more productive 
Enterprises that move because they need extra capacity will probably exhibit higher employment growth (Nakosteen and Zimmer 1987). But firms that are losing markets, finding themselves with excess capacity, may find it expedient to seek a smaller site in a different location as well. Both shrinking and rapidly expanding firms move, for both need different premises.

A firm that has been growing rapidly at any point in time will be larger than those that have not, other things being equal, while those in the early phase of development are likely to be small (Brouwer et al. 2004; van Dijk and Pellenbarg 2000) $)^{3}$. When controls for corporate age are included, the contribution of company size to mobility chances will reflect past growth. As the firm or its products mature and growth tails off, so will the need to move to larger premises and the relationship between mobility and corporate size will show a similar reduction. If recent expansion then requires a move to new larger premises, for given enterprise age;

\section{H3a. Greater company size (employment) increases the probability of relocation}

And

H3b. Expanding SMEs will increase employment by more if they relocate and conversely for contracting SMES

A corollary is that business migration will be influenced by the organisation of the enterprise. A firm run by an owner-manager with family commitments to a place will find transactions costs of mobility higher than those of an otherwise identical business with salaried career managers and active institutional shareholders. Subsidiaries, which will always be registered companies, will be especially mobile for this reason, but their effects will be captured by 'enterprise group relations', if there is more than one establishment in the organisation ${ }^{4}$. More personal forms of business organisation, perhaps less exclusively focussed on profit, include partnerships and sole proprietorships. Hence;

H4 Partnerships and sole proprietorships will be less mobile than companies.

and

H5 Subsidiaries will be more mobile than free-standing establishments

Takeovers are more likely to target high growth entrepreneurial SMEs, in their early phase. Acquisitions are an investment decision, an element of which may well be relocation to take advantage of synergies with the acquiring firm's assets. Regional takeover literature (Love 1989; Ashcroft et al 1994; Foreman-Peck and

\footnotetext{
${ }^{3}$ Brouwer et al (2004) in fact postulate that relocation chances diminish with size and find, using discrete employment categories, that firms with more than 1500 employees are less likely to move.

${ }^{4}$ Independent single site enterprises were less likely to relocate in a study of firms with more than 200 employees in 21 countries between 1997 and 1999 (5568 observations) (Brouwer et al 2004).
} 
Nicholls 2013) suggests that external control might have adverse effects on regional development. The headquarters of most large companies are now generally to be found in the geographical core region. Hence the likelihood is that a large company, to aid coordination and make full use of a newly acquired firm's assets, will move the target to the core. Hence

H6. Takeovers increase the chance of businesses relocating.

And

H7. Takeovers disproportionately relocate targets from the regional periphery to the core.

Even without takeovers, agglomeration economies, the advantages of proximity to concentrations of customers, to other firms and to business services can pull enterprises towards the large economic 'core' regions (Holl 2004; Barrios et al. 2005). On the other hand spatial concentrations of economic activity may generate higher costs, such as those due to congestion, or higher wages or rents, that push businesses out of the core towards peripheral regions; as neoclassical growth models assume, diseconomies of agglomeration are possible as well. Diseconomies may encourage some business emigration while economies may motivate other firms with different characteristics to move in to a region. Holl (2004) found that relocations (in Portugal 1986-1997) preferred areas with better national market accessibility, availability of producer services and a larger industrial base. Similarly with international investment and relocation, greater market demand proved more attractive to French firms (Procher 2011).

Such results suggest that market access matters, but lower unit costs - in the form of cheaper labour and land- in peripheral areas, labour 'availability' has been also found significant in explaining firm relocations (Twomey and Taylor 1985). If this second process dominates then we have (neoclassical) economic dispersal and if the first, concentration, as proposed by much NEG. The entrepreneurial or innovative firm life cycle approach may pull the spatial economy in either direction. The combination of congestion costs and innovation, external economies in production and market access suggest the possibility that flows out of the most innovative core region exceed flows in from other regions, regardless of relative regional size, if a predominately neoclassical process is at work. Then;

H8 The innovating core region will export SMEs and employment to the periphery

\section{Data, Definitions and Descriptive Statistics}

To test these hypotheses the present study utilises a very large official UK data set that is highly appropriate for the study of relocations, as comparatively rare events. This is the Business Structure Database (BSD) 
which is intended to identify all but the very smallest enterprises. Consequently, included in each year chosen for study here are almost two million cases, an annual snapshot of the 'Inter-Departmental Business

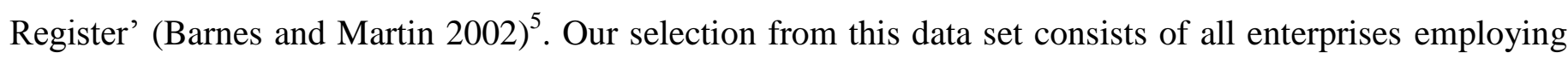
fewer than 250 persons. These enterprises are the smallest combination of legal units that is an organisation producing goods or services and that benefits from 'a certain degree of autonomy in decision-making' (ONS 2006, p. 7). Only 8 percent by number of the 2004 SME population were in manufacturing whereas one third were engaged in real estate, renting or providing business services (Appendix table 1). Just over one half of SMEs were companies and 18 percent were partnerships (Appendix table 2).

Although we have an almost complete coverage of the businesses of interest, the data set contains rather few characteristics. These are: address, industry classification (industrial/economic activity), employment, turnover, legal status (company, sole proprietor, partnership, public corporation/nationalised body, local authority or non-profit body) and enterprise group links. To employ the BSD for regional analysis we utilise the National Postcode Directory to assign enterprises to regions. For the relocation analysis we use the BSD's unique enterprise identifier to track each enterprise across the sampled years. A relocation is identified only if the establishment has moved regions; if in 2006 it was located in a different region from that originally recorded in 2004 (and registered with positive employment and turnover).

The BSD data set does not include innovation-related variables and data sets that do are unsuitable for linking because of their limited coverage ${ }^{6}$. But by way of background we outline the British NUTS1 regional pattern of innovative activity. SMEs and entrepreneurs are not necessarily the principal source of innovation in regional or national economies. Large, usually multinational, companies with systematic R\&D may undertake the bulk of measured $R \& D$ spending and patenting. The spatial pattern of innovation will therefore reflect both the location, usually of the head office, of these companies, as well as activities of much newer, dynamic, SMEs. Accordingly, more than one third of British patents were granted in the core regions of London and the South East, and grantees were dominated by a few large firms in the period of interest. The multinational Hewlett Packard was awarded 294 patents in 2004, more than those conferred in half the regions of Great Britain (Patent Office 2005). In the same year (and 2012) the South East dominated business and total R\&D (ONS 2014). London was not a R\&D high scorer because of the industrial composition ${ }^{7}$. London's top ranking among UK regions by Gross Value Added (GVA) per head depended

\footnotetext{
${ }^{5}$ Coverage is limited by voluntary registration for firms below the VAT registration threshold and the exclusion of employers whose employees are below the income tax exemption limit. Also businesses with a turnover above the VAT floor are not required to register if they trade exclusively in exempt goods (ONS 2007). Establishments may enter or leave the data set depending on whether they meet the VAT and income tax criteria in the different years.

${ }^{6}$ For instance the Community Innovation Survey and the Business Enterprise R\&D survey.

${ }^{7}$ Self-assessed measures of innovation show little UK regional variation in the proportion of innovation active firms, but this favours regions with more firms, London and the South East again. The proportion ranged from almost 70 per cent in Eastern
} 
upon financial and business services, whereas the pharmaceutical industry accounts for the largest proportion of UK business R\&D spending. However, London employed the highest regional proportion of science and engineering graduates and other graduates (Michie et al 2005 Table 4.2).

The capital variable required to calculate total factor productivity is not commonly available for such large datasets of SMEs. However, the BSD does have a measure of employment from which we can construct an index of enterprise labour productivity, following McGuckin and Nguyen (1995). This variable uses turnover as the output measure (in the absence of firm-level price deflators, turnover must be assumed to reflect output). To allow comparisons across different industrial sectors, the approach is to estimate each SME's productivity relative to the industry mean. This method removes industry-specific factors, such as differences in the capital stock and bought in materials, to create a 'relative labour productivity' index (RLP), which is an improvement on a simple labour productivity (Griffith et al. 2004).

An RLP index number greater than one indicates higher than the industry average productivity. For enterprise $\mathrm{i}$ in industry $\mathrm{j}$, and where LP is labour productivity and ALP is average industry labour productivity;

$\mathrm{RLP}_{\mathrm{ij}}=\mathrm{LP}_{\mathrm{ij}} / \mathrm{ALP}_{\mathrm{j}}$

Industries are defined at the 3-digit level of the UK SIC 1992 classification ${ }^{8}$. We also construct an industryrelative enterprise-level employment index $\left(\mathrm{rsize}^{\mathrm{E}}\right)$ as a measure of size.

Using this data set, figure 1 and table 1 (below) show the concentration of SMEs in the core regions of London and the South East, about one third of the 2004 GB stock. Table 1 indicates that around 1.5 percent of SMEs moved to another region of Great Britain between 2004 and 2006. London experienced the largest proportion of SMEs moving out (2.9 percent), followed by the East of England (1.7 percent). The smallest percentage of SMEs relocated from Scotland ( 0.43 percent), followed by Wales ( 0.75 percent) and the North East $(0.86$ percent). Figure 2 shows a similar pattern with the numbers of SMEs, allowing for the greater size of Scotland than the two other regions.

England to 55 per cent in London (Robson and Haigh 2008). These regional data reflect great industrial variation and industries will show different propensities to innovate (and patent).

${ }^{8}$ Only industries with 50 establishments or more are included in the data set. Productivity estimates include enterprises in

Northern Ireland but the analysis does not. 
Figure 1 - Total number of SMEs by region

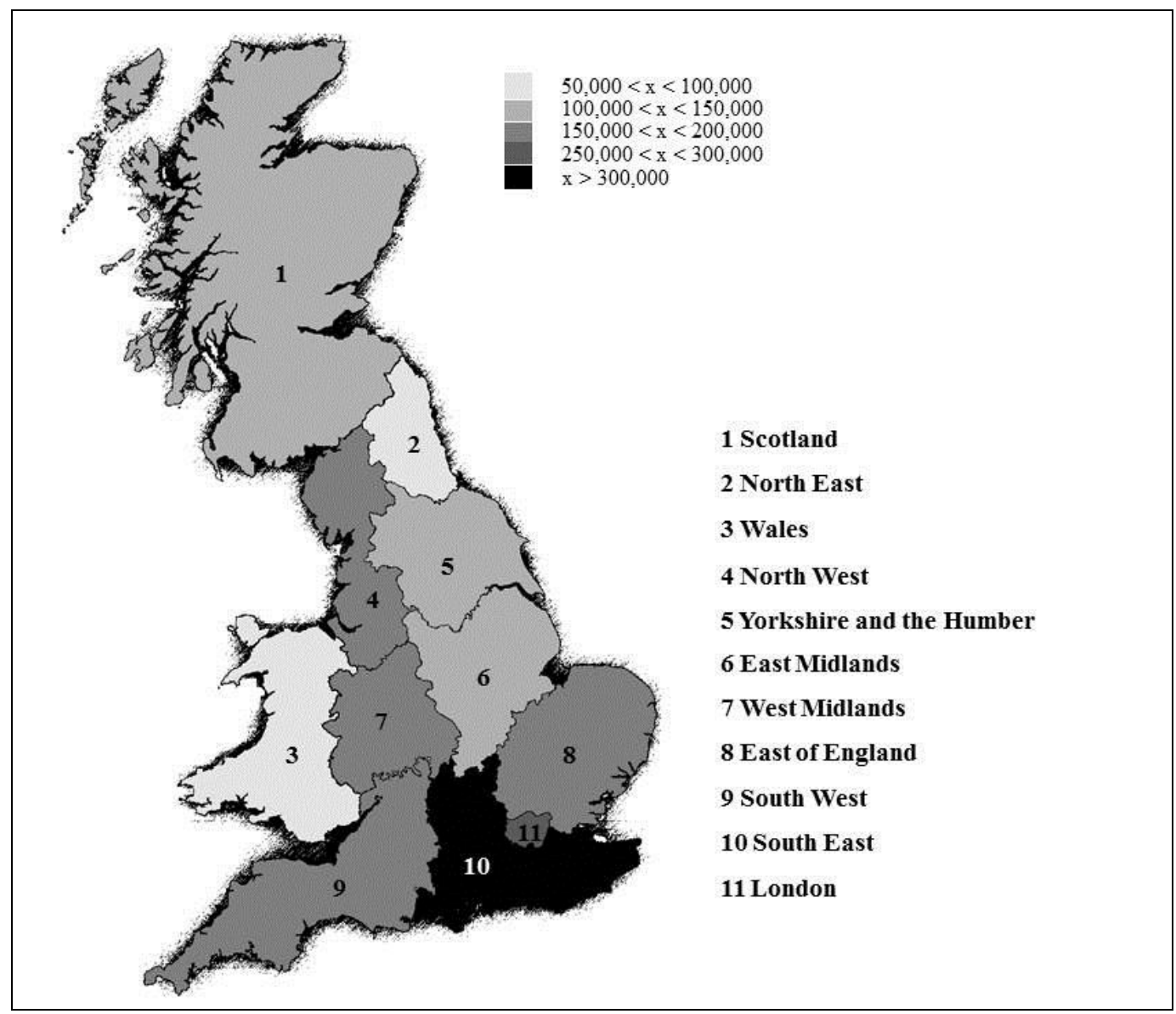

Figure 2 - SME gross exports by region

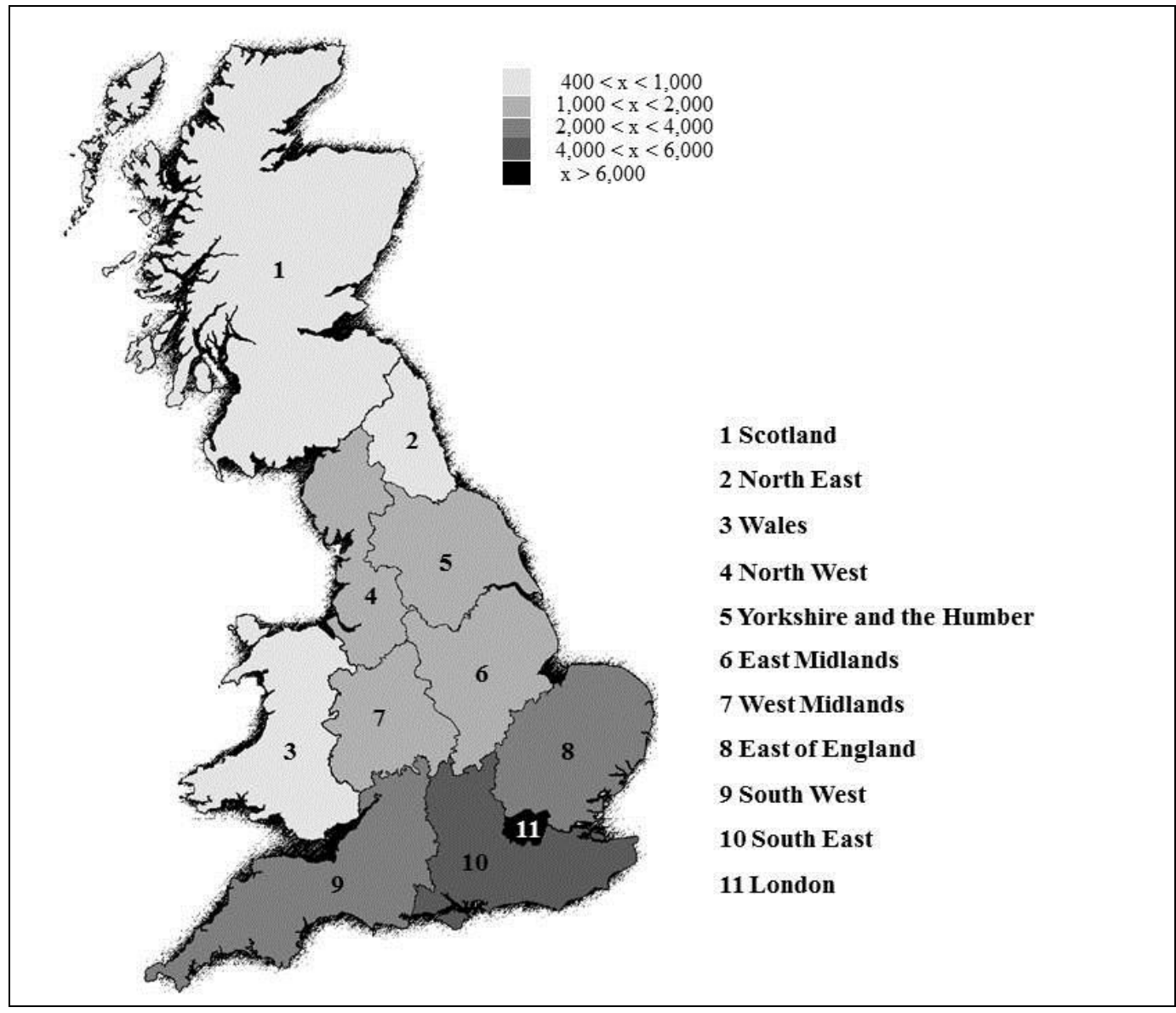




\section{Figure 3 - SME net imports by region}

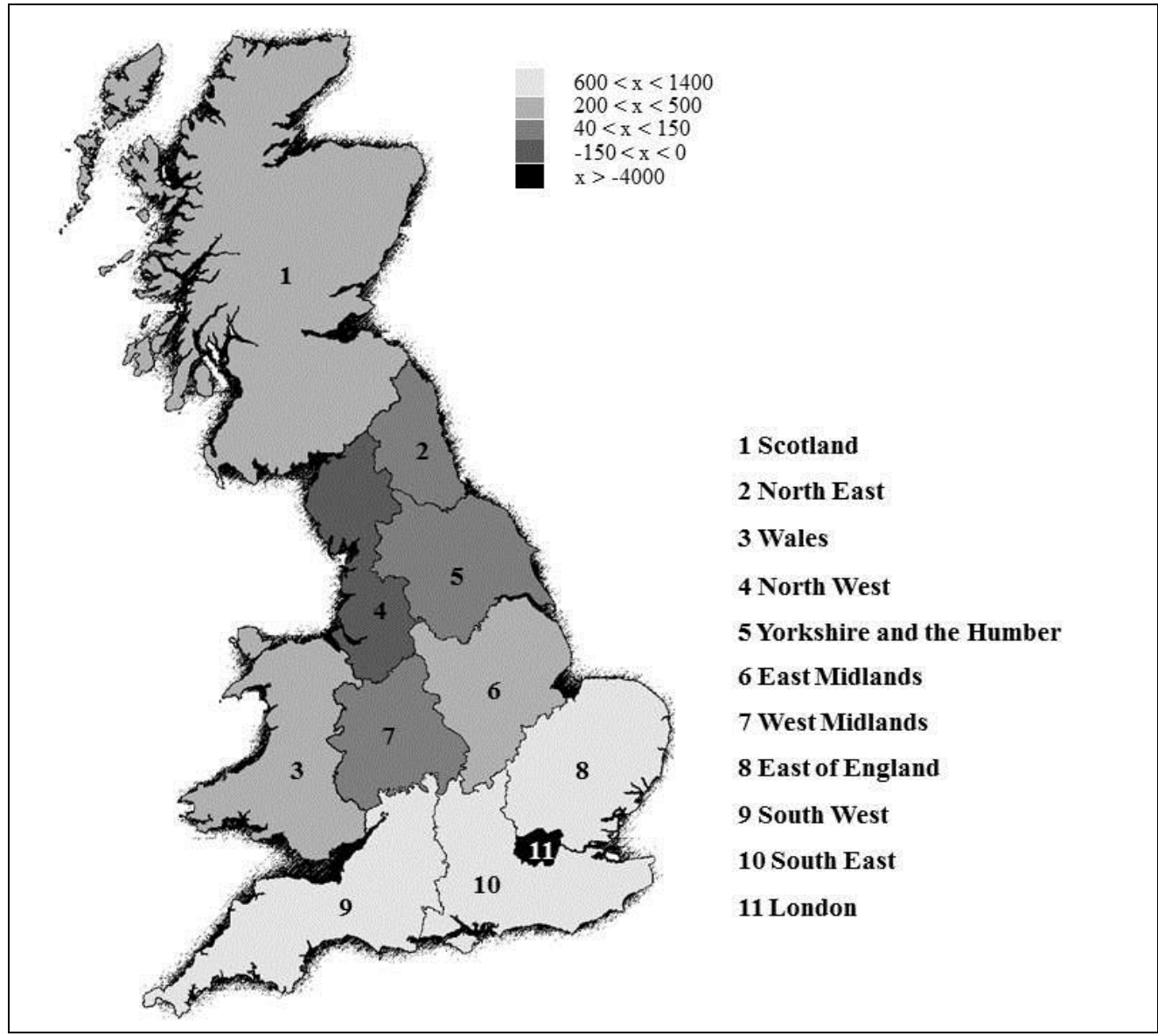

To identify which regions are net importers of SMEs the number emigrating from the region (third column) is subtracted from the number of incoming SMEs to the region (not shown). Only two regions - those with some of the largest UK conurbations - were net exporters of SMEs; the North West and London. All other regions of Britain were net recipients of SMEs (figure 3). Net imports as a percentage of the region's total are shown in the sixth column of table 1. London lost around 1.3 percent of its SMEs and the North West less than 0.1 percent. This is consistent with these areas generating a high proportion of expanding or innovative firms that then move out to lower cost areas in the mature product stage ${ }^{9}$ and with London as the industrial 'core' of hypothesis 8. In contrast to the findings of a study of manufacturing firm movements between 1960 and 1977 (Twomey and Taylor 1985), the South East in 2004-6 was a major importer of (all) enterprises. Other large proportionate gainers were the South West and Wales at around 0.4 percent each.

\footnotetext{
${ }^{9}$ The North West was the only region in the 1920s apart from London with more firm births than the South East in the interwar years (Foreman-Peck 1985 Table 4).
} 
Table 1 - SME relocation frequencies by UK region 2004-6

\begin{tabular}{lcccccc}
\hline & $\begin{array}{c}\text { Total SMEs } \\
\mathbf{( 2 0 0 4 )}\end{array}$ & SME imports & SME exports & $\begin{array}{c}\text { Net SME } \\
\text { imports }\end{array}$ & $\begin{array}{c}\text { Export \% } \\
\text { import \% }\end{array}$ & $\begin{array}{c}\text { Net SME } \\
\text { import }\end{array}$ \\
Wales & 85661 & $1020^{+}$ & 646 & $370^{+}$ & 0.75 & 0.44 \\
North East & 50117 & 487 & 432 & 55 & 0.86 & 0.11 \\
York. \& Hum. & 140990 & 1451 & 1369 & 82 & 0.97 & 0.06 \\
North West & 191125 & 1663 & 1786 & $\mathbf{- 1 2 3}$ & 0.93 & -0.06 \\
West Midlands & 160339 & $1950^{+}$ & $1830^{+}$ & 115 & 1.14 & 0.07 \\
East Midlands & 134121 & 2139 & 1894 & 245 & 1.41 & 0.18 \\
South West & 185228 & $2960^{+}$ & 2112 & $850^{+}$ & 1.14 & 0.46 \\
Scotland & 131365 & $860+$ & 564 & $300+$ & 0.43 & 0.23 \\
East England & 196822 & $4060^{+}$ & 3432 & $620^{+}$ & 1.74 & 0.32 \\
South East & 324909 & 6878 & 5508 & 1370 & 1.70 & 0.42 \\
London & 296611 & 4705 & 8600 & $-\mathbf{3 8 9 5}$ & 2.90 & -1.31 \\
\hline
\end{tabular}

Source: ONS and authors' calculations. Note: ${ }^{+}$rounded

Table 2 indicates where SMEs relocated, as well as their origins. The inter-regional flows of enterprises in the Table gives the location of SMEs in 2004 in the first column and their location in 2006 along the row. The table only includes SMEs that survived and were registered as active (with positive employment and turnover) between 2004 and 2006. It confirms that most SMEs did not relocate in the three year period; the diagonal contains the vast majority.

Table 2 also shows 'neighbour' effects. SMEs appear most likely to move to regions that are adjacent. For example, from Wales SMEs most commonly migrated to the West Midlands and North West. Information dissipates with distance and therefore mobility costs rise. Hence most establishments will not move far. Moreover some enterprises may migrate only a few miles but if they are located near a region's border they will be recorded as an inter-regional move because they cross the border ${ }^{10}$.

Net flows between London and the larger South East region (measured by the stock of SMEs) is in accordance with the greater 'pull' of the larger 'mass'; flows out of London to the South East are almost twice flows from the South East to London (Table 2). But net flows between London and other smaller regions show a similar pattern, contrary to the attraction of agglomeration. For instance, flows from London to the also contiguous Eastern Region are about twice those from the Eastern region to London. Consequently, smaller regions at first sight gain SMEs at the expense of London, the second largest region measured by SMEs. London exports more SMEs to the non-contiguous North East, Yorks, and the North West than does the larger South East region, consistent with H8, when London is the innovating core region.

\footnotetext{
${ }^{10}$ A finer set of spatial boundaries will identify more relocations because movements within an area are not measured. Official restrictions on the use of the BSD data base precluded access to individual enterprise full postcodes, however.
} 
Table 2 also shows London and the South East jointly sent more SMEs to the rest of Great Britain than they received from all other regions (rather more than two and a half thousand). For instance peripheral Wales sent $(78+79=) 157$ SMEs to London and the South East but received from the 'core' almost twice as many; $(138+164=) 302$.

Table 2 - SME relocations by UK region 2004-6

\begin{tabular}{|c|c|c|c|c|c|c|c|c|c|c|c|}
\hline From & To & & & & & & & & & & \\
\hline $\begin{array}{l}\text { No. of } \\
\text { relocations }\end{array}$ & N. East & N. West & $\begin{array}{c}\text { York. \& } \\
\text { Hum. }\end{array}$ & E. Mid. & W. Mid. & E. Eng. & London & S. East & S. West & Wales & Scot. \\
\hline N. East & 37,833 & 55 & 167 & 28 & $<20$ & $<20$ & 48 & 31 & $<20$ & $<20$ & 53 \\
\hline N. West & 97 & 145,128 & 280 & 151 & 254 & 102 & 198 & 232 & 108 & 206 & 158 \\
\hline York. \& Hum. & 126 & 273 & 107,930 & 372 & 90 & 75 & 131 & 138 & 62 & 28 & 74 \\
\hline E. Mid. & 32 & 146 & 340 & 102,102 & 338 & 317 & 176 & 308 & 135 & 41 & 61 \\
\hline W. Mid. & $<20$ & 235 & 82 & 371 & 123,136 & 113 & 200 & 260 & 315 & 188 & 50 \\
\hline E. Eng. & 33 & 167 & 110 & 369 & 151 & 150,040 & 1,257 & 959 & 250 & 55 & 81 \\
\hline London & 70 & 275 & 186 & 278 & 292 & 2,467 & 210,487 & 3,996 & 756 & 138 & 142 \\
\hline S. East & 52 & 222 & 164 & 395 & 363 & 735 & 2,105 & 244,075 & 1,150 & 164 & 158 \\
\hline S. West & 24 & 86 & 55 & 118 & 265 & 145 & 391 & 782 & 143,229 & 176 & 70 \\
\hline Wales & $<20$ & 119 & 25 & 25 & 149 & 39 & 78 & 79 & 111 & 67,505 & $<20$ \\
\hline Scot. & 30 & 85 & 42 & 32 & 33 & 45 & 121 & 93 & 63 & 20 & 101,492 \\
\hline
\end{tabular}

Source: ONS, authors' calculations. Note: diagonal elements are firms that do not move or do so only within the region.

SMEs that relocate were small on average (between 5 and 8 employees) but so were those that stayed. Entrepreneurial SME may be expected to be growing rapidly and so rather larger than this average. In Table 3 therefore attention is limited to enterprises employing more than 10 in 2004. The growth of employment among this group, between 2004 and 2007, averaged just over 9 percent while that among enterprises relocating by 2006 was more than double, an average of over 21 percent ${ }^{11}$. This supports hypothesis $3 b$ (Expanding SMEs will increase employment by more if they relocate...)

Consistent with Table 1, the fastest growing movers were companies originating in London and in the North West. This pattern might be expected if the North West and London were both 'core regions' from which rapidly growing innovative or entrepreneurial firms were likely to move away to take advantage of lower costs or congestion elsewhere (H8). In the peripheral regions of the North East, Yorkshire, East Midlands and Wales, employment among those moving out grew more slowly than among stayers, while in East of England, Scotland, Northern Ireland and the South East of England, the average employment change was negative, indicating downsizing.

\footnotetext{
${ }^{11}$ Restricting the sample to those employing more than 20 the percentages are 8 for the region as a whole and 14.6 for movers.
} 
Table 3 - Growth of Employment 2004-7 (Enterprises employing >10, 2004)

\begin{tabular}{lcccc}
\hline & \multicolumn{2}{c}{ Total Region } & \multicolumn{2}{c}{ Relocators Out 2006 } \\
& Mean & SE & Mean & SE \\
\hline North East & 0.1203 & 0.0145 & 0.0181 & 0.1940 \\
North West & 0.0912 & 0.0192 & 1.9368 & 1.8811 \\
Yorkshire & 0.0913 & 0.0129 & 0.0673 & 0.0914 \\
East Midlands & 0.1545 & 0.0756 & 0.0789 & 0.1038 \\
West Midlands & 0.0500 & 0.0107 & 0.1111 & 0.1135 \\
East England & 0.0582 & 0.0081 & -0.1046 & 0.0531 \\
London & 0.1211 & 0.0162 & 0.2785 & 0.1176 \\
South East & 0.0895 & 0.0195 & -0.0649 & 0.0585 \\
South West & 0.0614 & 0.0093 & 0.0970 & 0.0991 \\
Wales & 0.0536 & 0.0114 & 0.0429 & 0.1529 \\
Scotland & 0.1162 & 0.0247 & -0.0240 & 0.0978 \\
Northern Ireland & 0.0620 & 0.0115 & -0.7590 & 0.0933 \\
Total & 0.0907 & 0.0075 & 0.2168 & 0.1377 \\
\hline
\end{tabular}

Turning to the pattern of relative (nominal) labour productivity growth among mobile firms, Table 4 shows that here too performance on average is stronger (24 percent 2004-7) than among the region as a whole (16 percent) $(\mathrm{H} 2 \mathrm{~b})^{12}$. The geographical pattern is rather different from that for employment growth, however. SMEs migrating from London and the North West are no longer the fastest, though they both grow more strongly than stayers in those regions. If they move to take advantage of cheaper labour then labour productivity is of less concern in unit labour costs. Only movers from the South West, Wales and East Midlands show relative productivity growth slower on average than that of enterprises that stay behind.

\footnotetext{
${ }^{12}$ For enterprises employing more than 20, movers average 30 percent RLP growth and the regional average is 18 percent.
} 
Total Region

\begin{tabular}{lcccc} 
& Mean & SE & Mean & SE \\
\hline North East & 0.1463 & 0.0103 & 0.4134 & 0.1456 \\
North West & 0.1654 & 0.0061 & 0.2111 & 0.0975 \\
Yorkshire & 0.1619 & 0.0067 & 0.2151 & 0.0998 \\
East Midlands & 0.1460 & 0.0069 & 0.1406 & 0.1286 \\
West Midlands & 0.1656 & 0.0066 & 0.3258 & 0.1026 \\
East England & 0.1461 & 0.0065 & 0.3151 & 0.0736 \\
London & 0.1880 & 0.0074 & 0.2260 & 0.0534 \\
South East & 0.1512 & 0.0056 & 0.2938 & 0.0630 \\
South West & 0.1474 & 0.0068 & 0.0804 & 0.1044 \\
Wales & 0.1697 & 0.0097 & 0.0774 & 0.2363 \\
Scotland & 0.1735 & 0.0075 & 0.3536 & 0.1713 \\
Northern Ireland & 0.1656 & 0.0103 & 0.2108 & 0.6066 \\
Total & 0.1615 & 0.0021 & 0.2453 & 0.0276 \\
\hline
\end{tabular}

\section{Enterprise Level Multivariate Analysis of Relocations}

Taking the analysis beyond descriptive statistics, so as to isolate the individual effects of variables on the chances of an enterprise relocating for hypothesis testing, we estimate a probit equation. To establish the employment and productivity impact of mobile SMEs we use OLS regression. These approaches allow for regional heterogeneity as required by the core-periphery distinction.

\subsection{Estimation and Testing}

The model below shows the relocation estimating equation, where $\operatorname{Pr}$ is probability, $\mathrm{R}_{\mathrm{t}+1}=1$ if the firm has relocated in year $\mathrm{t}+1$ (2006) and $\Phi($.$) is the distribution (probit) function;$

$\operatorname{Pr}\left(\mathrm{R}_{\mathrm{t}+1}=1\right)=\Phi\left(\gamma_{0}\right.$ Location $_{\mathrm{t}-1}+\gamma_{1} \mathrm{Age}_{\mathrm{t}}+\gamma_{2} \ln \left(\mathrm{RLP}_{\mathrm{t}-1}\right)+\gamma_{21} \ln \left(\mathrm{RLP}_{\mathrm{t}-1}\right) * \ln \left(\mathrm{rsize}_{\mathrm{t}-1}^{\mathrm{E}}\right)+\gamma_{22}\left(\right.$ Location $_{\mathrm{t}-1} * \ln \left(\mathrm{RLP}_{\mathrm{t}-}\right.$ $\left.\left.{ }_{1}\right)\right)+\gamma_{3}\left(\operatorname{rsize}_{\mathrm{t}-1}^{\mathrm{E}}\right)+\gamma_{31} \ln \left(\text { rsize }_{\mathrm{t}-1}\right)^{2}+\gamma_{4}(\text { Legal form })_{\mathrm{t}-1}+\gamma_{5}(\text { Number of plants })_{\mathrm{t}-1}+\gamma_{6}$ Takeovers $_{\mathrm{t}-1}$

${ }_{{ }_{61}}\left(\right.$ Takeover $\left._{\mathrm{t}} * \ln \left(\mathrm{RLP}_{\mathrm{t}-1}\right)\right)+\gamma_{7} \ln \left(\right.$ Takeover $_{\mathrm{t}} *$ Location $\left._{\mathrm{t}-1}\right)+\gamma_{71}\left(\right.$ Takeover $_{\mathrm{t}} * \ln \left(\mathrm{RLP}_{\mathrm{t}-1}\right) *$ Location $\left._{\mathrm{t}-1}\right)$

Hypothesis 1 is the probability of relocation falls with enterprise age, $\gamma_{1}<0$. Hypothesis $2 \mathrm{a}$, that mobility chances increase with productivity, is that $\gamma_{2}>0$, but this is supplemented by a specification that allows the productivity effect to vary with the location and the size of the firm. Hypothesis $3 a, \gamma_{3}>0$, is that larger firms are more likely to be spatially mobile, but if $\gamma_{31}<0$ the effect diminishes and may even be reversed as size (employment) increases. Hypothesis $4\left(\gamma_{4}\right)$ is that more personal forms of ownership make for lower 
mobility. Hypothesis 5 is that partial mobility is more likely than full mobility so when the number of plants in the enterprise exceeds 1 relocation chances increase, $\gamma_{5}>0$. Hypothesis 6 is that a takeover raises the chances of the firm subsequently moving, $\gamma_{6}>0$, also allowing that these chances vary with the productivity of the target (as for instance predicted by Q theory (Jovanovic and Rousseau 2002)). Hypothesis 7, that takeovers affect relocation differentially according to the location of the target, is tested by whether $\gamma_{7} \neq 0$. These takeover effects are allowed also to vary with the productivity of the target.

If relocation is driven by the development and strategy of the well-managed, entrepreneurial enterprise such a business would be expected to grow more strongly than others. But relocation may also be a strategy of the contracting firm, perhaps in a later stage of the life cycle. For these firms conceivably the opposite would be the case; relocation would be an opportunity for downsizing more than companies that remained put. We check that this is so by considering the impact on productivity and employment of relocation separately for expanding and contracting firms. The focus must be upon the relocation effect among firms that survive the entire period of observation, so the basis is employment or productivity of survivors.

In contrast to equation 1 with relocation chances as dependent variable, equation 2 uses the 'differences in differences' form to explain the impact of relocation on employment or productivity at the enterprise level. Where $\Delta$ denotes the difference between the value in 2004 and 2007, and $\mathrm{Y}=$ employment or labour productivity;

$\Delta \mathrm{Y}=\beta_{0}$ Relocation $_{\mathrm{t}-1}+\beta_{1}$ Age $_{\mathrm{t}}+\beta_{2} \ln \left(\mathrm{RLP}_{\mathrm{t}-1}\right)+\beta_{22}\left(\right.$ Relocation $\left._{\mathrm{t}-1} * \ln \left(\mathrm{RLP}_{\mathrm{t}-1}\right)\right)+\beta_{3}\left(\right.$ rsize $\left._{\mathrm{t}-1}\right)+\beta_{4}\left(\operatorname{Legal}^{\mathrm{E}}\right.$

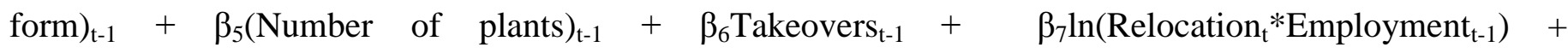
$\beta_{71}\left(\right.$ Relocation $_{\mathrm{t}}{ }^{\left.\text {Location }_{\mathrm{t}-1}\right)}+\beta_{8}$ Location

For expanding firms we expect $\beta_{0}>0$ and $\beta_{0}+\beta_{22} \ln \left(\mathrm{RLP}_{\mathrm{t}-1}\right)+\beta_{7} \ln$ Employment $_{\mathrm{t}-1}+\beta_{71}$ Location $_{\mathrm{t}-1}>0, \mathrm{H} 2 \mathrm{~b}$ when $\mathrm{Y}$ is productivity or $\mathrm{H} 3 \mathrm{~b}$ when $\mathrm{Y}$ is employment. Also for growing SMEs, if London functions as the spatial core region we expect positive contributions of SME net exports to employment so long as neoclassical convergence is occurring, $\mathrm{H} 8 ; \beta_{71}$ Relocation $_{\mathrm{t}}+\beta_{8}>0$, when Location indexes London location in 2004 and London differs from the national economy as a whole, where relocation is concerned ${ }^{13}$.

\subsection{Results}

The probit relocation model (1) of Table 5 uses identifiers for each region, omitting the South East and London (the 'core' as base case). Industry dummies are included but not reported for brevity. These

\footnotetext{
${ }^{13}$ Both equations 1 and 2 omit capital as an explanatory variable because it is not available in the BSD data base and too many cases would be lost by linking with other data bases that do include capital. We can assume that capital is correlated with labour . Then some of the estimated size effect measured by employment, and the industry effects, might be actually due to capital for both equations, but this should not bias the other coefficients of interest.
} 
dummies provide a way of assessing the approximate importance of manufacturing industries in firm mobility. We compare the average manufacturing industry marginal effect with the average for the sample as a whole. Unexpectedly in the whole sample, that includes mining, agriculture and utilities (but excluding financial intermediation as the base case), there is more mobility (average -0.09\%) than in manufacturing (sic15-36) (average -0.20\%). This is in large part due to sic 66-74 (including business services, 'activities auxiliary to financial intermediation' and other business activities) for which the average marginal effect was $+0.09 \%$. The high mobility of the SIC66-74 group is consistent with London's specialisation and hypothesised spatial role.

The age coefficients are all significantly different from the omitted case of 0 to 1 year, except for the 2 to 4 years category. Consistent with hypothesis 1 the coefficients indicate that older SMEs are less likely to relocate. Table 6 shows that a 2-4 year old enterprise is twice as likely to move as one that is over twenty years old. As noted above, this is likely to be due to life cycle effects or that newer firms have fewer local links, ensuring that relocation is less costly.

\section{<Table 5 about here>}

Table 6 - Predicted probability of relocation by age

\begin{tabular}{lc}
\hline Age group (years) & Probability of relocation \\
\hline Age 0 to 1 & $1.39 \%$ \\
Age 2 to 4 & $1.39 \%$ \\
Age 5 to 9 & $1.25 \%$ \\
Age 10 to 19 & $0.98 \%$ \\
Age $20+$ years & $0.68 \%$ \\
\hline
\end{tabular}

Source: ONS, authors' calculations

Note: Estimated at the sample average using only variables that are significant at 90 percent

Hypothesis 2a is confirmed by the positive and significant coefficient on productivity (RLP) but to establish the full productivity impact on relocation the interactions terms $\gamma_{21}$ and $\gamma_{22}$ must be included. Figure 1 shows the probability of relocation is around 0.4 to 1.8 percent over the three year period considered, depending on location and productivity. Relocation chances rise most strongly with productivity for firms in the East of England $^{14}$. Elsewhere the effect of productivity is rather mild. SMEs that are based either in London or the South East are most likely to relocate (including migration between these two regions). This is indicated by the negative coefficient for the region variables and is likely to be due to the effects of the firm/plant/product

\footnotetext{
${ }^{14}$ Notable for the Cambridge Science Park.
} 
life cycle and the 'core' position of these regions. Regions with the next highest probability of relocation are the East Midlands and East of England. The region with the lowest predicted probability of relocation is Scotland at all levels of productivity.

Figure 4 - Predicted probability of relocation by region and productivity

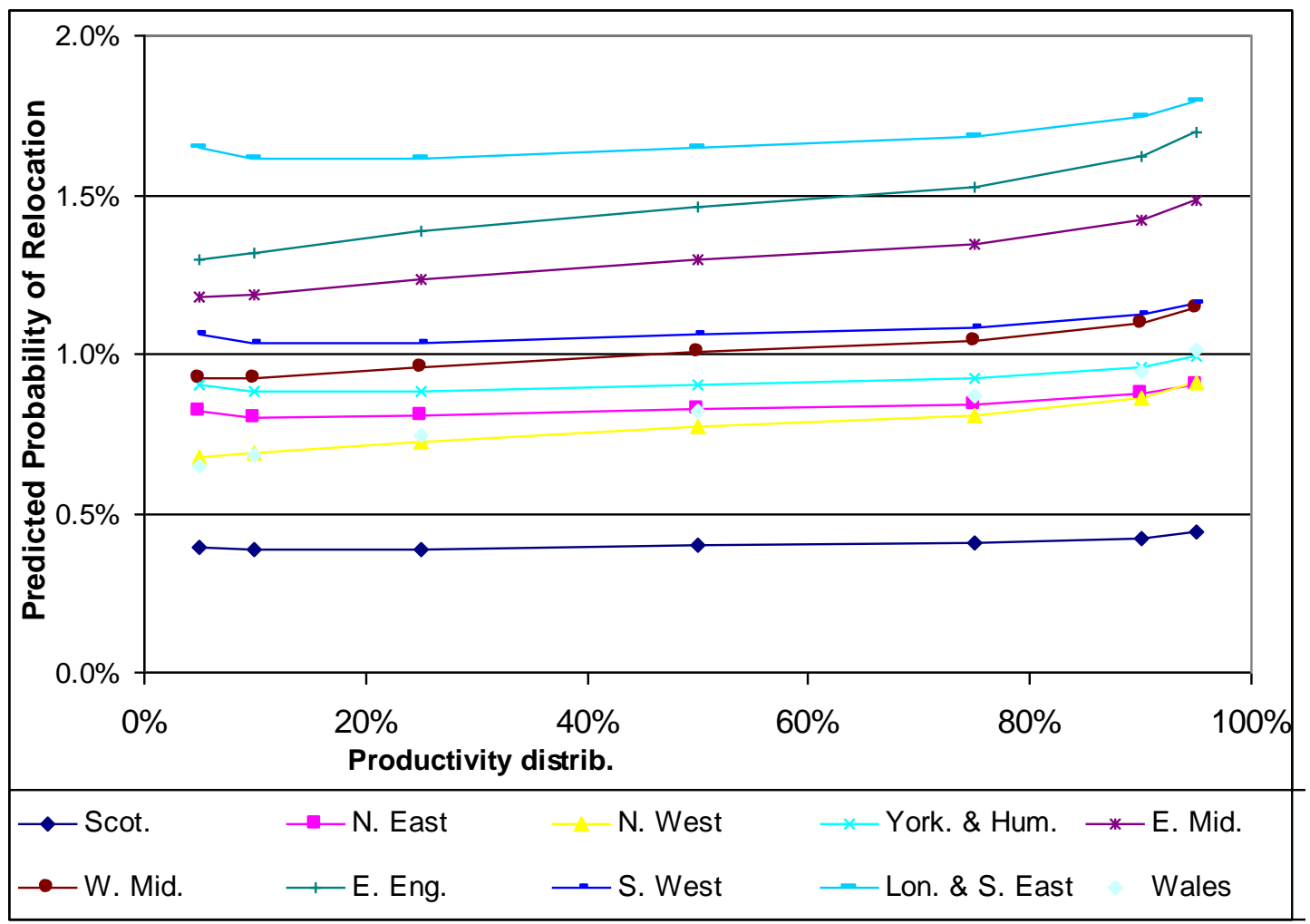

Source: ONS, authors' calculations

Note: Estimated at the sample average using only variables that are significant at 90 percent.

The actual values are shown in table A1

Confirming hypothesis $3 \mathrm{a}$, size (employment) is positive and significant in the model. Figure 2 shows the positive relationship between relative SME size and the probability of relocation has no tendency to diminish with enterprise size. Hypothesis 4, that more personal forms of business organisation are less likely to move, is borne out by Tables 5 and 7. The legal form coefficients of company and partnership are statistically significant (table 5). The predicted probability of relocation by business ownership/legal form is computed in table 7. As expected, companies have the highest probability of relocating, followed by sole proprietors and then partnerships. 
Figure 5 - Predicted probability of relocation by relative size

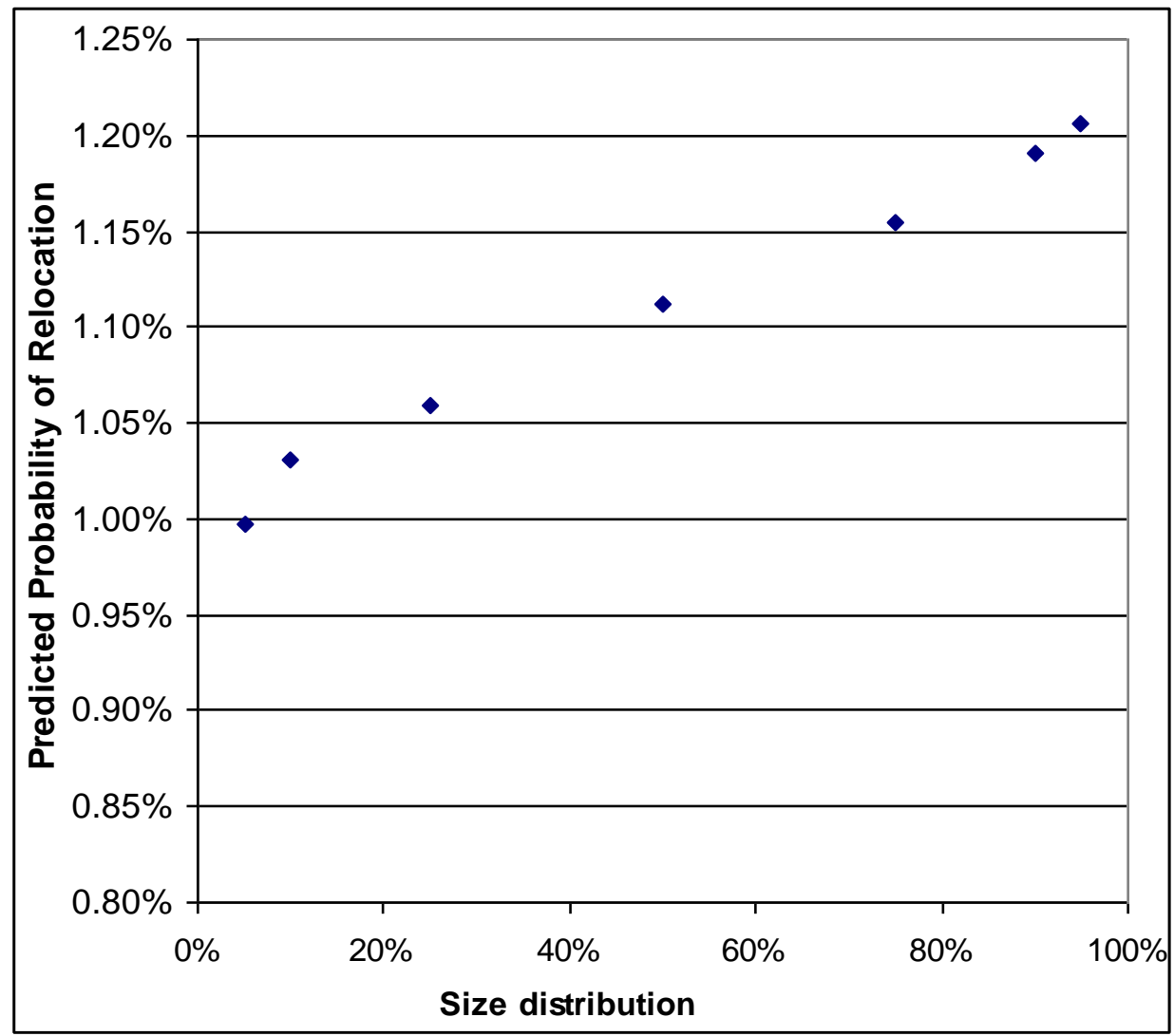

Source: ONS, authors' calculations

Note: Estimated at the sample average using only variables that are significant at 90 percent

Table 7 - Predicted probability of relocation by business ownership

\begin{tabular}{lc}
\hline Business ownership & Probability of relocation \\
\hline Sole Proprietor & $0.88 \%$ \\
Company & $1.50 \%$ \\
Partnership & $0.71 \%$ \\
\hline
\end{tabular}

Source: ONS, authors' calculations

Note: Estimated at the sample average using only variables that are significant at 90 percent

Hypothesis 5, that partial relocation is more likely than full relocation for a firm is confirmed in Table 5. The number of plants has a positive relationship with the probability of relocating.

The takeover variable in the relocation model is significant and positive (Table 5) (hypothesis 6). Some of the region-takeover variables are also significant and positive (hypothesis 7) but the productivity-takeover interaction is not. For all regions takeovers increase the chances of relocation (Table 8). The largest effect is for SMEs in the North East (2.78 percent) and Scotland (1.97 percent). The smallest marginal effect is for SMEs in the East Midlands (0.45 percent), East England (0.49 percent) and London and the South East (0.55 
percent). Whereas a takeover in Wales triples the chances of relocation away from Wales, a London takeover only increases the probability of movement out of London by one third. This may be a source of policy concern in the periphery. But takeovers also have other impacts on productivity and survival chances of SMEs, which act in the opposite direction to relocation effects for peripheral regions (Foreman-Peck and Nicholls 2013).

Table 8 - Predicted probability of relocation by takeover

\begin{tabular}{lccc}
\hline Region & No takeover & Takeover & Marginal effect of takeover \\
\hline Wales & $0.79 \%$ & $2.53 \%$ & $1.74 \%$ \\
North East & $0.81 \%$ & $3.59 \%$ & $2.78 \%$ \\
York. \& Hum. & $0.89 \%$ & $1.92 \%$ & $1.03 \%$ \\
North West & $0.75 \%$ & $1.83 \%$ & $1.08 \%$ \\
\hline West Midlands & $0.98 \%$ & $2.51 \%$ & $1.53 \%$ \\
East Midlands & $1.27 \%$ & $1.72 \%$ & $0.45 \%$ \\
Scotland & $0.39 \%$ & $2.36 \%$ & $1.97 \%$ \\
East England & $1.43 \%$ & $1.93 \%$ & $0.49 \%$ \\
South West & $1.05 \%$ & $2.43 \%$ & $1.38 \%$ \\
\hline London \& S. East & $1.63 \%$ & $2.18 \%$ & $0.55 \%$ \\
\hline
\end{tabular}

Note: Estimated at the sample average using only variables that are significant at 90 percent Source: ONS, authors' calculations

In summary, the probit estimates of equation 1 show that spatially mobile SMEs are more productive, usually larger and younger. They are more likely to be registered as companies, taken-over and originally based in London and the South East.

Relocation employment and productivity impacts, as described in equation 2, are shown in Table 9. Among SMEs with positive employment growth between 2004 and 2007 the direct effect for those that relocated was to expand labour productivity by 8.5 percent more than those that did not, in line with the life cycle of the entrepreneurial firm (Table 9 'relocation06' regression $9.3^{15}$ ). This conclusion must be qualified by the significant interaction terms- with employment and with productivity ('Reloc* emp04' and 'Reloc*RLP'); larger employers that moved raised employment, though the opposite effect is found for more productive SMEs. Ignoring for the moment the London effect for movers, at the (growing) sample means the net effect of mobility is slightly larger at 10.2 percent, confirming hypothesis $2 \mathrm{~b}$ (Expanding SMEs that relocate are

${ }^{15} 100 *[\exp (.082)-1]$ 
likely to become more productive) ${ }^{16}$. But on average larger (employment increasing) firms - those employing more than 20 - raised productivity when relocating by much more, by 29.4 percent $^{17}$ (regression 9.1) (the interaction terms were not statistically significant).

The effect was not, however, continuous over the entire size range; (growing) SMEs employing more than 50 persons did not enhance their productivity by relocating according to the direct effect. Yet the interaction coefficient with productivity ('reloc*RLP') was significant and -0.235; the more productive the larger SME that moved, the lower the subsequent productivity boost. But with mean labour productivity of -0.58 the relocation effect even for these larger SMEs is positive and yields a coefficient of 0.136 at the mean, close to the statistically insignificant direct effect, and providing a 14.6 percent productivity increase.

\section{<Table 9 About Here>}

Employment effects perhaps surprisingly are proportionately bigger over the range of firm size tested. Relocating SMEs that have positive employment growth raise employment by $(0.129 \rightarrow) 13.8$ percent compared to growing firms that do not move (regression 9.6). Those with more than twenty employees create $(0.199 \rightarrow) 22$ percent more jobs, while those employing more than 50 enhance employment by $(0.301 \rightarrow) 35$ percent apparently as a result of relocating.

Table 9 shows that takeovers ('takeover05') increase productivity and employment among expanding SMEs. Regional effects include that London-based SMEs ('London04') increased employment and productivity relative to all other expanding firms except Scotland's ('Scot04' for employment) (regressions. 9.3 and 9.6). But contrary to the descriptive statistics, those London-based enterprises that moved did so by rather less ('reloc*lond'). Nonetheless they boosted employment for the average mover by ('relocation06'+'reloc*lond' $=0.129-0.0407=0.088 \rightarrow$ ) 9.2 percent, which in view of the volume of London's SME net exports (Table 2), must constitute a significant contribution to reducing regional disparities. This conclusion, which confirms hypothesis 8 , is strongly reinforced by the greater percentage employment expansion of larger SMEs, for which there was no significant movement from London offset (regressions 9.4 and 9.5, 'reloc*lond'). The net negative productivity effect for London-based movers reflects the selection of lower wage regions; the incentive to increase labour productivity is reduced or eliminated when lower labour costs are anyway incurred by relocation.

\footnotetext{
$\left.{ }^{16}(+.0822+(.00194 * 5.4109)-(.0808 *-.06292))=\right) 0.098$ and $(100 *(\exp (.098)-1)=10.2$.

${ }^{17}$ Coefficient on 'relocation06'. $(100 *(\exp (0.258)-1)=)$.
} 
Controlling for other factors, SMEs in Wales raised relative productivity between 2004 and 2007 by less than any other British region (regression 9.3, 'wales04'). Where employment expansion is concerned, growing SMEs in the East and West Midlands performed least well. To the extent that the industry controls in the regression models are sufficiently fine grained, this effect cannot be attributed to local industrial structure, which perhaps leaves local labour markets as the most obvious explanation.

Turning to the smaller number of contracting SMEs, we see that inter-regional relocation has a mirror effect; just as mobility helps expansion it also permits or is associated with stronger contraction (Table 10). Among contracting firms, those that move reduce employment by more ('relocation06' $<0$, regression 10.1) (though this effect cannot be found for larger SMEs, regression 10.3). Whereas cutting employment may be helpful for profits, reducing productivity is not. Presumably mobility for smaller enterprises - the majority - causes unanticipated problems of downward adjustments whereas for firms employing more than 50 there is no statistically significant relocation effect on productivity (regression 10.5).

Takeovers reduced employment and productivity among these contracting SMEs, although for larger enterprises there was no productivity impact either way. For the average contracting SME, moving out of London is associated with employment and productivity expansion (10.1 and 10.4), consistent with achieving cost or other advantages from their new sites. SMEs employing more than 20 workers increased employment by $(100 *[\exp (0.2)-1]=) 22$ percent (regression 10.2) thanks to their mobility. Although this was not sufficient to offset the overall fall in employment among movers in this contracting sample, the number of SMEs involved was smaller than in the expanding sample. As would be expected if London's economic agglomeration increased the intensity of competition there relative to other regions, London-based enterprises that contracted shrunk faster than those elsewhere ('London04' $<$ ). In the North East of England and Wales, contracting SMEs reduced employment by the least, other things being equal, suggesting competition was less pressing in these peripheral regions (regression 10.1).

\section{<Table 10 About Here>}

\section{Conclusion}

The product life cycle and associated changes within the entrepreneurial firm can create incentives to relocate, particularly away from high cost core locations. Most firms do not relocate; those that do are special and therefore of particular interest for regional policy. SMEs that move between regions are likely to be more productive than the average, perhaps because they have made the transition from a development stage into a production phase. Or they may be unusual because their management are sufficiently organised to make a rational decision about where the firm can operate most effectively, in contrast to the often largely randomly located site where the entrepreneur began it all. Or an SME may be moved because it has been taken over, and yet not shut down because the acquirer appreciates its value as a going concern. While in all 
such cases the migration of the enterprise is likely to be a loss to the home region and a gain to the new host region, every UK region except London and the North West on balance gained relocating SMEs between 2004 and 2006; they were net hosts to incoming enterprises.

Larger firms (up to the 249 employment limit of the present study) are more probably able to pay the fixed costs of relocation and so are more likely to relocate. On the other hand younger firms tend to be smaller but more dynamic- ready to change between phases of a product cycle. Combined with being less firmly embedded in their locality, younger firms are therefore more likely to move between regions. Takeovers also increase the chances of relocation. Consistent with the lifecycle of the entrepreneurial firm, among British SMEs with positive employment growth between 2004 and 2007 relocation expanded labour productivity by 10 percent more than for growing SMEs that did not move. Such firms raised employment by even more, by almost 14 percent. Employment effects were proportionately bigger as firm size increased, so that for SMEs employing more than 50, the impact of relocation was 35 percent.

Agglomeration economies and diseconomies offer reasons for moving between regions with different phases of a product or business lifecycle. SMEs are more likely to relocate if they are initially based in the more populous and richer regions of London and the South East. Although London-based SMEs increased their employment and productivity relative to all other expanding firms except Scotland's, contrary to the descriptive statistics, those that moved did so by rather less. Nonetheless the average mover boosted employment by 9 percent, which in view of the volume of London's SME net exports, must constitute a significant contribution to reducing regional disparities. The net negative productivity effect for expanding, London-based movers reflects their selection of lower wage regions. For the average contracting SME, moving out of London is associated with employment and productivity expansion, consistent with achieving cost or other advantages from their new sites. If London's economic agglomeration increased the intensity of competition, then London-based enterprises that contracted would shrink faster than those elsewhere, as in fact we find.

These results are consistent with a neoclassical convergence of economic activity between core and periphery, through the movement of numbers of SMEs. SME mobility does not increase the relative size of the core regions of London and the South East, as commonly predicted by NEG models. This market process (but not necessarily others) on balance is a centrifugal, rather than a centripetal force.

The numbers involved means that mobility of such firms alone may exercise only a small effect in the short term but the longer term impacts of their higher productivity and perhaps growth rates could be important. The thrust of current regional policy, such as it is, has been to stimulate inward investment (usually from abroad) and promote indigenous start-ups. But the potential of SME movements has not escaped all policy 
makers, who have in the past provided subsidies to promising indigenous businesses. An extreme illustrative case is the insurance company Admiral, which originated in 1991 in London (in a fashion consistent with Audretsch's (1995) knowledge spillover theory of entrepreneurship). Offered large financial incentives by the Welsh Development Agency, the business began trading in 1993 in Cardiff with 57 employees. By the end of 2013 Admiral employed 5000 in South Wales (7000 world-wide), was the only Welsh company in the FTSE-100 and had triggered the development of other financial services companies in Wales ${ }^{18}$. If policymakers can find ways of identifying core-based SMEs with high growth potential then the market process of regional dispersal could be reinforced to the benefit of more peripheral regions.

Since expanding smaller businesses that relocate, grow faster, a less radical policy implication is that obstacles to relocation should be minimised as far as possible. One such obstacle could be difficulties in obtaining planning permission for new sites. Certainly this motivated the proposal in the 2012 UK Budget to simplify planning regulations (Martin 2012). Perhaps the difficulties of downsizing relocation, apparent in the productivity decline of smaller SMEs, could be alleviated as well by this policy.

Acknowledgments This research was supported by the Economic and Social Research Council and Welsh Assembly Government (Grant Number PTA-040-2006-00004). The work contains statistical data from the Office of National Statistics (ONS), which is Crown copyright and reproduced with the permission of the controller of Her Majesty's Stationery Office and Queen's Printer for Scotland. The use of the ONS statistical data in this work does not imply the endorsement of the ONS in relation to the interpretation or analysis of the statistical data. This work uses research data sets which may not exactly reproduce National Statistics aggregates.

18 http://www.admiralgroup.co.uk/story/index.php 


\section{$\underline{\text { References }}$}

Ashcroft, B. and Taylor, J. 1977 The movement of manufacturing industry and the effect of regional policy Oxford Economic Papers 29, March, pp. 84-101.

Ashcroft, B. Coppins, B. and Raeside, R. 1994. The Regional Dimension of Takeover Activity in the United Kingdom Scottish Journal of Political Economy 41(2), pp. 163-175.

Asheim, B.T., and Coenen, L. 2005. Knowledge bases and regional innovation systems: Comparing Nordic clusters. Research Policy 34:1 173-90.

Asheim, B and Gertler, M 2005 The Geography of Innovation: Regional Innovation Systems, in: Fagerberg, D C. Mowery \& R R Nelson (eds), The Oxford Handbook of Innovation, Oxford: Oxford University Press, pp. 291-317.

Audretsch, D. B. 1995. Innovation and industry evolution. Cambridge, Mass.: MIT Press

Audretsch, D. B. and Feldman, M. P. 1996. Innovative clusters and the industry life cycle. Review of Industrial Organization 11(2), pp. 253-273.

Audretsch, D., and Lehmann, E. 2005. Does the knowledge spillover theory of entrepreneurship hold for regions? Research Policy 34:1 191-202.

Baldwin, R. E., and Forslid, R. 2000. The core-periphery model and endogenous growth: Stabilizing and destabilizing integration. Economica, 267, pp. 307-324.

Baldwin, R. E., and Okubo, T. 2006. Heterogeneous firms, agglomeration and economic geography: Spatial selection and sorting. Journal of Economic Geography, 6(3), pp. 323-346.

Barnes, M. and Martin, R. 2002. Business Data Linking: An introduction. Economic Trends 581.

Barrios, S,. Bertinelli, L., Strobl E. and Teixeiraet A-C. 2005. The dynamics of agglomeration: evidence from Ireland and Portugal, Journal of Urban Economics 57 pp.170-188.

Barro, R and Sala-i-Martin X. 2004, Economic Growth, Cambridge Mass, MIT Press.

Biggeiro L. 2006 Industrial and knowledge relocation strategies under the challenges of globalization and digitalization: the move of small and medium enterprises among territorial systems, Entrepreneurship and Regional Development 186 pp. 443-471.

de Bok, M. and van Oort, F. 2011. Agglomeration economies, accessibility, and the spatial choice behavior of relocating Firms Journal of Transport and Land Use 41 pp. 5-24.

Brouwer, A. E., Mariotti,I.and. van Ommeren, J. N. 2004. The firm relocation decision: An empirical investigation. The Annals of Regional Science 38(2), pp. 335-347.

Checkland S G 1976 The Upas Tree: Glasgow, 1875-1975, University of Glasgow Press.

Cooke, P 2002. Knowledge economies. Clusters, learning and cooperative advantage. London: Routledge.

Copus, A. Skuras, D. and Tsegenidi, K. 2008. Innovation and Peripherality: An Empirical Comparative Study of SMEs in Six European Union Member Countries, Economic Geography 84 1 51-82. 
Coucke, K. Pennings, E. and Sleuwaegen, E. 2007. Employee Layoff under Different Modes of Restructuring: Exit, Downsizing or Relocation. Industrial and Corporate Change 16(2), pp. 161-182.

Duranton, G. and Puga, D., 2001. Nursery Cities: Urban Diversity, Process Innovation, and the Life Cycle of Products, American Economic Review 91, 5 pp. 1454-1477.

Fagerberg, J (2005) Innovation: A Guide to the Literature, in: J Fagerberg, D C Mowery and R R Nelson (eds), The Oxford Handbook of Innovation, Oxford: Oxford University Press, pp. 1-26.

Figueiredo O., Guimarães P. and Woodward D. 2002 Home-field advantage: location decisions of Portuguese entrepreneurs. Journal of Urban Economics 52 pp. 341-361.

Fisher, R. A. (1930) The Genetical Theory of Natural Selection, Oxford, Clarendon Press.

Foreman-Peck J. 1985 Seedcorn or Chaff? New Firm Formation and the Performance of the Interwar Economy, Economic History Review 38 pp. 402-422.

Foreman-Peck J. and Nicholls T. 2013 SME takeovers as a contributor to regional productivity gaps, Small Business Economics 412 359-378.

Fothergill S and Gudgin G 1982 Unequal Growth: Urban and Regional Employment Change in the UK, Heineman, London.

Galbraith, C.S., Rodriguez, C. L. and DeNoble A.F. 2008 SME Competitive Strategy and Location Behavior: An Exploratory Study of High-Technology Manufacturing, Journal of Small Business Management 46 pp. 183-202.

Griffith, R., Redding S. and Simpson H. 2004. Foreign Ownership and Productivity: New Evidence from the Service Sector and the R\&D Lab. Oxford Review of Economic Policy 20(3), pp. 440-456.

Gudgin, G. 1978 Industrial Location Processes and Regional Growth, Saxon House, Hants.

H M Treasury 2001. Productivity in the UK: The Regional Dimension. November.

Holl, A. 2004. Start- ups and relocations: Manufacturing plant location in Portugal. Papers in Regional Science 83(4), pp. 649-668.

Hu, W, Cox, L J, Wright J and Harris T R 2008. Understanding Firms' Relocation and Expansion Decisions Using Self-Reported Factor Importance Rating Review of Regional Studies 38, 1 pp. 67-88.

Jovanovic, B., and Rousseau, P. L. 2002. The Q-theory of mergers. American Economic Review, 92(2) pp. 198-204.

Keeble D and Tyler P 1995 Enterprising Behaviour and the Urban-Rural Shift, ESRC Centre for Business Research, University of Cambridge Working Paper no.4.

Knoben, J. and Oerlemans, L. A. G. 2008a. Ties that Spatially Bind? A Relational Account of the Causes of Spatial Firm Mobility. Regional Studies 42(3), pp. 385-400.

Knoben, J., Oerlemans, L. A. G. and Rutten, R.P.J.H. 2008b The Effects of Spatial Mobility on the Performance of Firms. Economic Geography, 84, 2 , pp. 157-183. 
Krugman P. R. 1991 Increasing Returns and Economic Geography Journal of Political Economy 993 pp. 483-499.

Lee S. Y., Florida R. and Acs Z. J. (2004) Creativity and entrepreneurship: a regional analysis of new firm formation, Regional Studies38, 879-891.

Loasby B J 1988 Making Location Policy Work (Lloyds Bank Review, Jan 1967), republished in Behavioural Economics, Volume 2 (ed. Peter Earl), Edward Elgar.

Loasby B J 2000 Decision Processes, Decision Cycles and Decomposition Industrial and Corporate Change 9 (4).

Love J. H. 1989 External takeover and regional economic development: a survey and critique, Regional Studies 23.

Lundvall, B-Å 1999 Technology policy in the learning economy, in: D Archibugi, J Howells and J Michie (eds), Innovation Policy in a Global Economy, Cambridge: Cambridge University Press, pp. 19-34.

Manjon-Antolin M.C. and Arauzo-Carod, J-M 2011 Locations and relocations: determinants, modelling, and interrelations, Annals of Regional Science 47 pp. 131-146.

Martin D. 2012 Budget 2012: Fears for countryside as controversial planning reforms get the go ahead, Daily Mail 21 March.

McGuckin, R. H. and Nguyen, S. V. 1995. On Productivity and Plant Ownership Change: New Evidence from the Longitudinal Research Database. The RAND Journal of Economics 26(2) pp. 257-276.

Michie, J., Oughton, C. and Frenz, M. 2005. The Community Innovation Survey: An Analysis for Scotland, Report for the Scottish Executive. http://www.scotland.gov.uk/Resource/Doc/981/0007446.pdf.

Nakosteen, R. A. and Zimmer, M. A. 1987. Determinants of Regional Migration by Manufacturing Firms. Economic Inquiry 25(2), pp. 351-362.

OECD (2013), “Gazelles rate”, in Entrepreneurship at a Glance 2013, OECD Publishing. http://dx.doi.org/10.1787/entrepreneur_aag-2013-19-en.

ONS. 2006. Regional, sub-regional and local gross value added [Online]. Available at: http://www.statistics.gov.uk/statbase/Product.asp?vlnk=14650 [Accessed: December 2006].

ONS. 2007. Inter Departmental Business Register (IDBR) - A Brief Guide [Online].

Available at: http://www.statistics.gov.uk/idbr/idbr.asp .

ONS 2014 UK Gross Domestic Expenditure on Research and Development Regional Tables 2001 - 2012 http://www.ons.gov.uk/.

Patent Office, 2005 Facts and Figures 2004-2005 Department of Trade and Industry, UK.

Procher, V. 2011 Agglomeration Effects and the Location of FDI: Evidence from French First-Time Movers, Annals of Regional Science, 46, 2, pp. 295-312. 
Ramajo, J, Marquez, M. A., Hewings, G J. D. and Salinas, M. M. 2008. Spatial Heterogeneity and Interregional Spillovers in the European Union: Do Cohesion Policies Encourage Convergence across Regions?_European Economic Review, April 52, 3, pp. 551-67.

Ravenstein, E. G. 1885 The Laws of Migration, Journal of the Statistical Society of London, 482 pp. 167235.

Robson, S. and Haigh, G ., 2008 First findings from the UK Innovation Survey 2007 Economic \& Labour Market Review 2, 4 April , 47-53.

Rodríguez-Pose, A., and Fratesi, U. 2004 Between Development and Social Policies: The Impact of European Structural Funds in Objective 1 Regions. Regional Studies. 38 1, pp. 97-113.

Samuelson, P. A. 1948. International Trade and the Equalisation of Factor Prices, Economic Journal, June, pp. 163-184.

Stam, E. 2007. Why Butterflies Don't Leave. Locational behaviour of entrepreneurial firms. Economic Geography 83(1), pp. 27-50.

Sternberg, R., and Arndt, 0. 2001.The firm or the region:What determines the innovation behavior of European firms? Economic Geography 77:364-82.

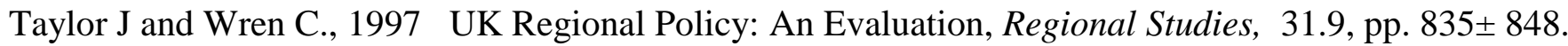

Twomey, J. and Taylor, J. 1985. Regional Policy and the Interregional Movement of Manufacturing Industry in Great Britain. Scottish Journal of Political Economy 32(3), pp. 257-277.

van Dijk, J. and Pellenbarg, P. H. 2000. Firm relocation decisions in the Netherlands: An ordered logit approach. Papers in Regional Science 79(2), pp. 191-219.

Venables A. J. 2006 Shifts in Economic Geography and their Causes CEP Discussion Paper No 767 December.

Vernon, R.1966. International trade and international investment in the product cycle. Quarterly Journal of Economics (June), pp. 190-207. 
Table 5- Probit regression estimates of relocation

\begin{tabular}{|c|c|}
\hline Variable & $\begin{array}{c}\text { Dep var relocation } \\
\text { Full sample }\end{array}$ \\
\hline Takeover & $0.1191^{* * *}$ \\
\hline $\operatorname{Ln}(R L P)$ & $0.0291^{* * *}$ \\
\hline $\operatorname{Ln}(R L P)^{\wedge} 2$ & $0.0108^{* * *}$ \\
\hline Age 2 to 4 & 0.0101 \\
\hline Age 5 to 9 & $-0.0424^{* * *}$ \\
\hline Age 10 to 19 & $-0.1345^{\star \star *}$ \\
\hline Age $20+$ years & $-0.2684^{\star \star *}$ \\
\hline Ln(local unit) & $0.1007^{\star * \star}$ \\
\hline Ln(remp) & $0.0191^{* * *}$ \\
\hline $\operatorname{Ln}(\text { remp })^{\wedge} 2$ & $-0.0060^{* \star *}$ \\
\hline Company & $0.2045^{\star \star *}$ \\
\hline Partnership & $-0.0788^{\star * *}$ \\
\hline Wales & $-0.2555^{\star \star *}$ \\
\hline Scot. & $-0.5263^{\star * *}$ \\
\hline N. East & $-0.2693^{\star * *}$ \\
\hline N. West & $-0.2823^{* \star *}$ \\
\hline York. \& Hum. & $-0.2332^{* \star *}$ \\
\hline E. Mid. & $-0.0887^{\star \star *}$ \\
\hline W. Mid. & $-0.1891^{\star * *}$ \\
\hline E. Eng. & $-0.0390^{\star \star \star *}$ \\
\hline S. West & $-0.1734^{* \star *}$ \\
\hline Wales* $\ln (\mathrm{RLP})$ & $0.0424^{* * *}$ \\
\hline Scot. ${ }^{*} \ln (\mathrm{RLP})$ & -0.0141 \\
\hline N. East*In(RLP) & 0.0213 \\
\hline N. West*In(RLP) & $0.0240^{\star *}$ \\
\hline York. \& Hum. ${ }^{*} \ln (\mathrm{RLP})$ & 0.0176 \\
\hline E. Mid. ${ }^{*} \ln (\mathrm{RLP})$ & $0.0182^{*}$ \\
\hline W. Mid. ${ }^{*} \operatorname{n}(\mathrm{RLP})$ & $0.0159^{\star}$ \\
\hline E. Eng. ${ }^{*} \ln (R L P)$ & $0.0238^{* * *}$ \\
\hline S. West*In(RLP) & 0.0096 \\
\hline Wales*takeover & $0.3401^{* *}$ \\
\hline Scot. ${ }^{\star}$ takeover & $0.5586^{* * *}$ \\
\hline N. Easttakeover & $0.4861^{* * *}$ \\
\hline N. Westtakeover & $0.2223^{* * *}$ \\
\hline York. \& Hum. *takeover & $0.1793^{\star *}$ \\
\hline E. Mid. ${ }^{\star}$ takeover & 0.0454 \\
\hline W. Mid. ${ }^{*}$ takeover & $0.2568^{* * *}$ \\
\hline E. Eng.*takeover & 0.0930 \\
\hline S. Westtakeover & $0.2182^{\star *}$ \\
\hline Takeover*In(RLP) & 0.1191 \\
\hline Industry & $\mathrm{Y}$ \\
\hline N & $1,897,288$ \\
\hline Pseudo $R^{2}$ & 0.05 \\
\hline Log-likelihood & $-139,117$ \\
\hline
\end{tabular}

Note: ${ }^{*} p<0.1 ;{ }^{* *} p<0.05 ;{ }^{* * *} p<0.01$

Source: ONS, authors' calculations 
Table 9 - Relocation Effects on Employment and Labour Productivity for SMEs

Expanding Employment 2004-7: OLS Regressions

\begin{tabular}{|c|c|c|c|c|c|c|}
\hline & \multicolumn{3}{|c|}{$\begin{array}{l}\text { Log Difference in Relative Labour Productivity } \\
2004-7 \text { by initial size }\end{array}$} & \multicolumn{3}{|c|}{$\begin{array}{c}\text { Log Difference in Employment 2004-2007 } \\
\text { by initial size }\end{array}$} \\
\hline & $\begin{array}{c}\text { Emp04>20 } \\
(9.1)\end{array}$ & $\begin{array}{c}\text { Emp04 }>50 \\
(9.2)\end{array}$ & $\begin{array}{c}\text { All } \\
(9.3)\end{array}$ & $\begin{array}{c}\text { Emp04>50 } \\
(9.4)\end{array}$ & $\begin{array}{l}\text { Emp04>20 } \\
(9.5)\end{array}$ & $\begin{array}{c}\text { All } \\
(9.6)\end{array}$ \\
\hline relocation06 & $0.258 * *$ & 0.138 & $0.0822 * * *$ & $0.301 * * *$ & $0.199 * * *$ & $0.129 * * *$ \\
\hline takeover05 & $0.0957 * * *$ & $0.0978 * *$ & $0.187 * * *$ & 0.0304 & $0.0335^{*}$ & $0.0549 * * *$ \\
\hline lnRLP04_3d i & $-0.274 * * *$ & $-0.291 * * *$ & $-0.272 * * *$ & $0.0461 * * *$ & $0.0590 * * *$ & $0.118 * * *$ \\
\hline Inlu04 & $-0.0406^{* * *}$ & $-0.0413 * * *$ & $-0.0403 * * *$ & $0.0150 * *$ & $0.0159 * * *$ & $0.0705 * * *$ \\
\hline employment04 & $0.000522 * * *$ & $0.000502 * * *$ & $0.000824 * * *$ & 0.0000362 & $-0.00041 * * *$ & $-0.00429 * * *$ \\
\hline Reloc* emp04 & -0.00021 & 0.000399 & $0.00194 * * *$ & -0.00147 & -0.000688 & 0.000344 \\
\hline age 2to4 & $-0.473 * * *$ & $-0.646 * * *$ & $0.00572 *$ & -0.00874 & -0.0107 & $-0.0971 * * *$ \\
\hline age 5to9 & $-0.663 * * *$ & $-0.834 * * *$ & $-0.0660 * * *$ & $-0.126^{*}$ & $-0.0846 * * *$ & $-0.214 * * *$ \\
\hline age10to19 & $-0.752 * * *$ & $-0.914 * * *$ & $-0.0974 * * *$ & $-0.194 * * *$ & $-0.170 * * *$ & $-0.280 * * *$ \\
\hline age20plus & $-0.813 * * *$ & $-0.980 * * *$ & $-0.145^{* * *}$ & $-0.235^{* * *}$ & $-0.220 * * *$ & $-0.339 * * *$ \\
\hline company04 & 0.00297 & $0.105^{*}$ & $0.148 * * *$ & -0.0151 & 0.0198 & $0.00463 *$ \\
\hline partnersh 04 & $-0.122 * * *$ & 0.00185 & $-0.0334 * * *$ & $-0.145 * * *$ & $-0.0748 * * *$ & $-0.123^{* * *}$ \\
\hline reloc*RLP & -0.0944 & $-0.235 * *$ & $-0.0808 * * *$ & 0.0645 & 0.06 & -0.022 \\
\hline reloc*lond & $-0.221 * *$ & $-0.321 *$ & $-0.0908 * * *$ & 0.123 & 0.137 & $-0.0407^{*}$ \\
\hline reloc*nw & -0.0407 & -0.256 & -0.0522 & 0.0771 & -0.0216 & 0.0023 \\
\hline London04 & $0.193 * * *$ & $0.227 * * *$ & $0.101 * * *$ & $0.0319 *$ & $0.0257 * *$ & $0.0286^{* * *}$ \\
\hline nwest04 & -0.0129 & 0.00758 & $-0.0180 * * *$ & $0.0342 * *$ & 0.0139 & $0.0168 * * *$ \\
\hline wales04 & $-0.0424 * *$ & -0.0289 & $-0.0446^{* * *}$ & 0.0115 & $-0.0207 *$ & $0.0161 * * *$ \\
\hline $\operatorname{scot} 04$ & -0.0215 & -0.0127 & $0.0124 * * *$ & 0.0206 & 0.00949 & $0.0356 * * *$ \\
\hline yorkhum04 & $-0.0401 * * *$ & -0.0234 & $-0.0183 * * *$ & $0.0336 * *$ & $0.0238 * *$ & $0.0105 * * *$ \\
\hline wmid04 & $-0.0242 *$ & $-0.0453^{*}$ & $-0.00967 * * *$ & 0.0165 & 0.0123 & -0.0000862 \\
\hline eeng04 & -0.0121 & -0.0318 & -0.0011 & -0.000531 & 0.0041 & -0.00232 \\
\hline neast04 & $-0.0451^{* *}$ & $-0.0524 *$ & $-0.0265^{* * *}$ & $0.0380^{*}$ & $0.0402 * * *$ & $0.0202 * * *$ \\
\hline swest04 & $-0.0390 * * *$ & $-0.0478 *$ & $-0.0240 * * *$ & -0.00868 & -0.000567 & $0.00900 * *$ \\
\hline _cons & $0.952 * * *$ & $0.913 * * *$ & $0.222 * * *$ & $0.617 * * *$ & $0.615 * * *$ & $1.144 * * *$ \\
\hline $\mathrm{N}$ & 40687 & 14172 & 699428 & 9197 & 25866 & 334209 \\
\hline adj. R-sq & 0.225 & 0.248 & 0.205 & 0.095 & 0.104 & 0.159 \\
\hline
\end{tabular}

Note: industry dummies included but not reported

Standard errors in parentheses

$* \mathrm{p}<0.05, * * \mathrm{p}<0.01, * * * \mathrm{p}<0.001$ 
Table 10 - Relocation Effects on Employment and Labour Productivity for SMEs Contracting Employment

2004-7: OLS Regressions

\begin{tabular}{|c|c|c|c|c|c|c|}
\hline & \multicolumn{3}{|c|}{$\begin{array}{l}\text { Log Difference in Employment 2004-7 } \\
\text { by initial size }\end{array}$} & \multicolumn{3}{|c|}{$\begin{array}{c}\text { Log Difference in Relative Labour Productivity 2004-7 } \\
\text { by initial size }\end{array}$} \\
\hline & $\begin{array}{c}\text { All } \\
(\mathbf{1 0 . 1})\end{array}$ & $\begin{array}{c}\text { empl04>20 } \\
(10.2)\end{array}$ & $\begin{array}{c}\text { empl04>50 } \\
(10.3)\end{array}$ & $\begin{array}{c}\text { All } \\
(\mathbf{1 0 . 4})\end{array}$ & $\begin{array}{c}\text { empl04>50 } \\
(10.5)\end{array}$ & $\begin{array}{c}\text { empl04 }>20 \\
(10.6)\end{array}$ \\
\hline relocation06 & $-0.162 * * *$ & $-0.497 * * *$ & -0.412 & $-0.167 * * *$ & -0.0912 & $-0.281 * * *$ \\
\hline takeover05 & $-0.0761 * * *$ & $-0.0582 *$ & $-0.101^{*}$ & $-0.0761 * * *$ & 0.0134 & -0.0119 \\
\hline lnRLP04_3d i & $0.0369 * * *$ & $0.0872 * * *$ & $0.0883 * * *$ & $-0.0843 * * *$ & $-0.165 * * *$ & $-0.154 * * *$ \\
\hline lnlu04 & $0.0442 * * *$ & $0.0629 * * *$ & $0.0625 * * *$ & $-0.0481 * * *$ & -0.0161 & $-0.0252 * *$ \\
\hline employment04 & -0.000074 & $-0.000524 * * *$ & $-0.000510 * *$ & $0.00389 * * *$ & -0.0000325 & 0.0000539 \\
\hline Reloc*emp04 & $-0.00330 * * *$ & 0.000298 & -0.0000945 & -0.000863 & 0.0000335 & $0.00167 *$ \\
\hline age2to4 & $0.175^{* * *}$ & $0.804 * * *$ & $1.185 * * *$ & $0.164 * * *$ & 0.0615 & $0.137 *$ \\
\hline age 5 to 9 & $0.223 * * *$ & $0.938 * * *$ & $1.389 * * *$ & $0.256 * * *$ & $0.209^{*}$ & $0.235^{* * * *}$ \\
\hline age10to19 & $0.263 * * *$ & $1.082 * * *$ & $1.547 * * *$ & $0.261 * * *$ & $0.273^{* *}$ & $0.316^{* * * *}$ \\
\hline age20plus & $0.319 * * *$ & $1.168 * * *$ & $1.645 * * *$ & $0.266 * * *$ & $0.329 * * *$ & $0.366^{* * *}$ \\
\hline company04 & $0.00665^{* *}$ & $0.253 * * *$ & $0.336 * * *$ & $-0.133 * * *$ & 0.0959 & $0.0932 * * *$ \\
\hline partnersh $\sim 04$ & $0.113 * * *$ & $0.304 * * *$ & $0.352 * * *$ & 0.00374 & 0.106 & $0.105 * * *$ \\
\hline Reloc* RLP & $-0.0245 * *$ & -0.0244 & -0.0192 & $-0.0434 * * *$ & -0.033 & -0.0607 \\
\hline Reloc*lond & $0.0816^{* * *}$ & $0.205^{*}$ & 0.248 & $0.0395^{*}$ & 0.0383 & -0.0934 \\
\hline Reloc*nw & 0.00794 & 0.229 & 0.065 & 0.0712 & 0.0286 & 0.0386 \\
\hline London04 & $-0.0607 * * *$ & $-0.131 * * *$ & $-0.160 * * *$ & $0.0154 * * *$ & -0.0245 & $-0.0396^{*}$ \\
\hline nwest04 & 0.0061 & $0.0287 *$ & 0.00357 & $0.0523 * * *$ & -0.0182 & -0.00914 \\
\hline wales 04 & $0.0269 * * *$ & $0.0434 *$ & 0.0225 & $0.0135 * *$ & 0.00848 & 0.0261 \\
\hline$s \cot 04$ & -0.00431 & -0.00467 & -0.0333 & $0.0253 * * *$ & -0.0343 & -0.019 \\
\hline yorkhum04 & $0.0204 * * *$ & $0.0495^{* *}$ & $0.0543 *$ & $0.0336 * * *$ & 0.00934 & 0.00688 \\
\hline wmid04 & 0.00651 & 0.00199 & -0.0213 & $0.0373 * * *$ & -0.0346 & -0.00182 \\
\hline eeng04 & 0.0049 & -0.0058 & -0.0273 & $0.0349 * * *$ & -0.0238 & -0.00638 \\
\hline neast04 & $0.0339 * * *$ & 0.0354 & 0.0366 & $0.0517 * * *$ & -0.0133 & -0.00678 \\
\hline swest04 & $0.0156^{* * *}$ & 0.0137 & -0.00125 & $0.0198 * * *$ & 0.028 & 0.0147 \\
\hline _cons & $-0.748 * * *$ & $-1.577 * * *$ & $-2.062 * * *$ & $-1.090 * * *$ & $-1.584 * * *$ & $-1.544 * * *$ \\
\hline $\mathrm{N}$ & 244649 & 28655 & 10286 & 588016 & 6643 & 21895 \\
\hline adj. R-sq & 0.068 & 0.171 & 0.213 & 0.071 & 0.109 & 0.101 \\
\hline
\end{tabular}




\section{Appendix}

\section{A1. SMEs by Industry in 2004}

\begin{tabular}{lcc}
\hline Industry & Frequency & Percentage of sample \\
\hline Agriculture, hunting and forestry & 136,243 & $7.18 \%$ \\
Fishing & 3,670 & $0.19 \%$ \\
Mining and quarrying & 972 & $0.05 \%$ \\
Manufacturing & 157,103 & $8.28 \%$ \\
Electricity, gas and water supply & 430 & $0.02 \%$ \\
Construction & 212,483 & $11.20 \%$ \\
Wholesale and retail trade; repair of motor vehicles, & & \\
motorcycles and personal and household goods & 386,126 & $20.35 \%$ \\
Hotels and restaurants & 134,493 & $7.09 \%$ \\
Transport, storage and communication & 82,171 & $4.33 \%$ \\
Financial intermediation & 22,962 & $1.21 \%$ \\
Real estate, renting and business activities & 609,385 & $32.12 \%$ \\
Other community, social \& personal service activities & 151,250 & $7.97 \%$ \\
Total & $1,897,288$ & $100 \%$ \\
\hline
\end{tabular}

\section{A2. SME Firm Type}

\begin{tabular}{lcc}
\hline Firm type & $\mathbf{N}$ & $\mathbf{\%}$ \\
\hline Company & 967,787 & $51.0 \%$ \\
Partnership & 337,643 & $17.8 \%$ \\
Sole proprietor & 591,858 & $31.2 \%$ \\
Total & $1,897,288$ & $100 \%$ \\
\hline
\end{tabular}


